Gut, 1963, 4, 155

\title{
Hypoalbuminaemia due to protein loss from gastric carcinoma
}

\author{
PAUL TURNER, G. S. C. SOWRY, AND P. M. O'DONNELL, \\ From Edgware General Hospital, Middlesex
}

EDITORIAL SYNOPSIS In a patient suffering from carcinoma of the stomach generalized oedema was the presenting symptom. It is suggested that this was due to excessive loss of protein from the stomach.

Hypoalbuminaemia is commonly found in lesions of the gastrointestinal tract, and in recent years isotope studies have shown that this may be due to loss of protein from the bowel, as well as to impaired synthesis of albumin by the liver.

In the case to be described, albumin loss in a patient with carcinoma of the stomach produced such a marked degree of hypoalbuminaemia that the presenting sign was generalized oedema which was so severe that the original clinical diagnosis lay between advanced renal and hepatic disease. The possibility of protein-losing enteropathy became more conspicuous as these were excluded. The nature of the lesion causing this loss was not conclusively established until laparotomy.

Carcinoma of the stomach has been shown to be capable of causing such a marked loss of albumin (Schwartz and Jarnum 1959; Jarnum and Schwartz 1960; Heiskell, Wada, Stempien, Fukuda, Nakagawa, Yachi, Dagradi, and Carpenter, 1961), but this is as yet not widely recognized. For this reason, and in order to illustrate the value of methods of investigation described by Jeejeebhoy and Coghill (1961), the following case record is presented.

\section{CASE HISTORY}

A 66-year-old storeman was admitted to Edgware General Hospital in February 1962 with a story of increasing oedema of the hands and legs for one month. There were few symptoms; in particular he did not complain of breathlessness on exertion, of nocturia, of dysuria. He was a man who made little of his disabilities and it was therefore difficult to assess his gastrointestinal symptoms. On direct questioning he denied any, but it was probable that he had had a period of anorexia and perhaps occasional vomiting. He denied any pain.

On examination he was a pale, sallow, wasted man with massive pitting oedema of the legs up to and including the anterior abdominal wall, sacral oedema, and oedema of the hands and forearms. There was no evidence of cardiac failure and his heart was clinically normal. Abdominal examination showed moderate ascites and slight hepatomegaly but no other abnormality. His blood pressure was $120 / 80 \mathrm{~mm}$. $\mathrm{Hg}$. There was no proteinuria.

INITIAL INVESTIGATIONS The haemoglobin was $10.2 \mathrm{~g}$./ $100 \mathrm{ml}$. (68\%), white cell count $17,700 / \mathrm{c} . \mathrm{mm}$., with a normal differential count, and the red cells showed moderate anisocytosis, hypochromasia, and poikilocytosis. The E.S.R. was $8 \mathrm{~mm}$./hour (Westergren). Serum electrolytes were: sodium 130 , potassium $4 \cdot 8$, and chloride $100 \mathrm{mEq}$./litre respectively. The blood urea was $36 \mathrm{mg} . / 100 \mathrm{ml}$. Liver function tests, including the transaminases, were normal. Total plasma proteins were $4.9 \mathrm{~g} . / 100 \mathrm{ml}$., and electrophoresis showed a marked decrease in the albumin fraction (Fig. 1). Excretion of bromsulphalein was normal, and a liver biopsy showed no abnormality apart from a little periportal fatty change. A glucose tolerance test gave a fasting level of $135 \mathrm{mg}$./ $100 \mathrm{ml}$., with readings at half-hourly intervals after $50 \mathrm{~g}$. of glucose of $140,135,125$, and $115 \mathrm{mg} . / 100 \mathrm{ml}$.

Further examination of the urine showed no proteinuria on any occasion. The urinary 17-ketosteroid and 17-hydroxycorticosteroid excretion was 1.8 and $5 \cdot 2 \mathrm{mg} . / 24$ hours respectively.

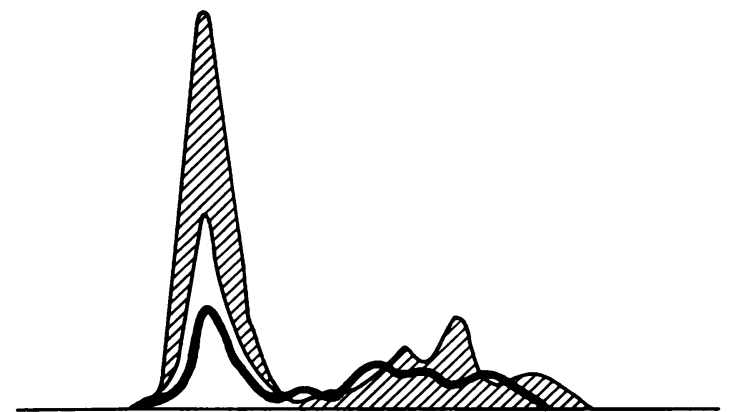

FIG. 1. Electrophoretic strip of plasma proteins of patient (thick line) compared with that of normal (cross-hatched). 
TABLE

PATIENT'S AND NORMAL VALUES COMPARED

\begin{tabular}{|c|c|c|c|c|c|c|}
\hline & $\begin{array}{l}\text { Serum } \\
\text { Albumin } \\
(\mathrm{g} . / 100 \mathrm{ml} .)\end{array}$ & $\begin{array}{l}\text { Total } \\
\text { Exchangeable } \\
\text { Albumin } \\
\text { (g./kg.) }\end{array}$ & $\begin{array}{l}\text { Total } \\
\text { Catabolism } \\
(\mathrm{mg} . / \mathrm{kg} . / \text { day })\end{array}$ & $\begin{array}{l}\text { Faecal } \\
\text { Excretion } \\
\text { (mg./kg./day) }\end{array}$ & $\begin{array}{l}\text { Endogenous } \\
\text { Catabolism } \\
(\mathrm{mg} . / \mathrm{kg} . / \text { day })\end{array}$ & $\begin{array}{l}\text { Synthesis } \\
\text { Rate } \\
\text { (mg./kg./day) }\end{array}$ \\
\hline $\begin{array}{l}\text { Normal values (Jeejeebhoy, 1962) } \\
\text { Patient's values }\end{array}$ & $\begin{array}{l}3 \cdot 5-4 \cdot 2 \\
2 \cdot 0\end{array}$ & $\begin{array}{l}3 \cdot 8-5 \cdot 0 \\
1 \cdot 17\end{array}$ & $\begin{array}{l}140-290 \\
365\end{array}$ & $\begin{array}{l}28-60 \\
300\end{array}$ & $\begin{array}{l}100-218 \\
64\end{array}$ & $\begin{array}{l}150-290 \\
360\end{array}$ \\
\hline
\end{tabular}

Examination of the stools showed persistently positive occult blood tests, and faecal fat excretion over a threeday period was $2 \cdot 7 \mathrm{~g} . / 24$ hours.

$X$-ray films of the chest were normal. A barium meal showed at least 2 pints of residual fluid and food. No filling defect was seen in the stomach, but the duodenal cap was small and deformed and suggested duodenal scarring with pyloric stenosis.

ISOTOPE STUDIES (Dr. K. N. Jeejeebhoy) There being no protein loss in the urine and no evidence of severe liver disease, albumin turnover studies were carried out to investigate the cause of the low plasma albumin. The method used was that described by Jeejeebhoy and

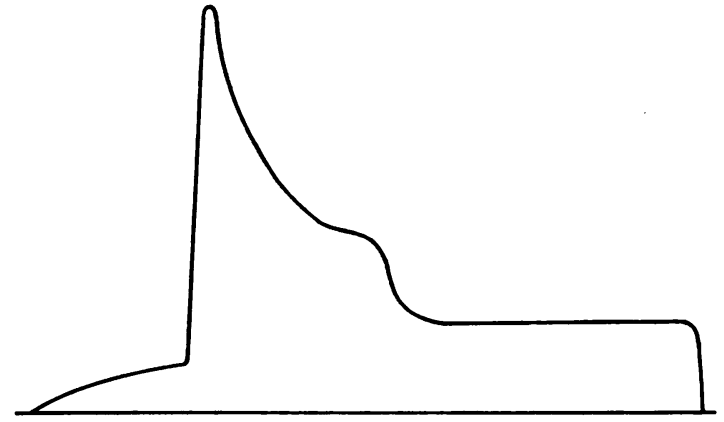

FIG. 2. Electrophoretic strip of gastric juice concentrated 10 times showing prominent albumin band.

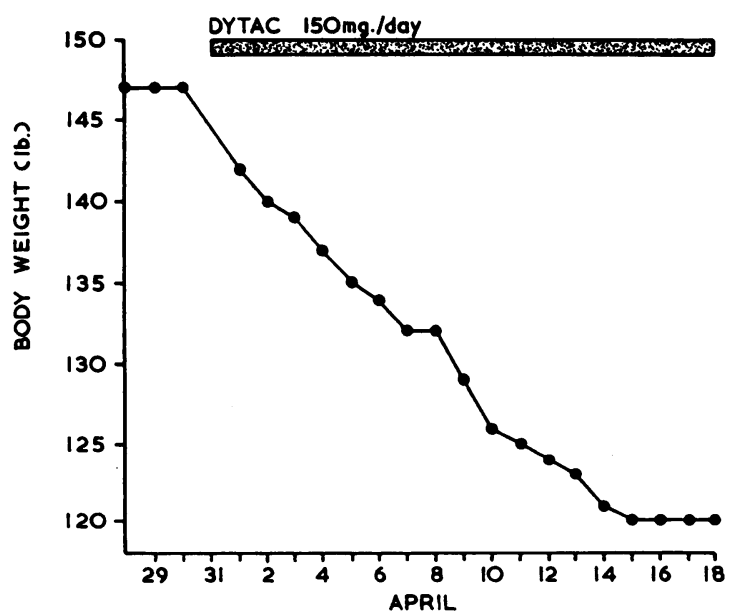

FIG. 3. Graph showing fall in body weight associated with diuretic therapy.
Coghill (1961), and the results are shown in the Table. They demonstrate an abnormal faecal excretion of albumin, with a resulting low total exchangeablealbumin level, despite an increased rate of synthesis. The latter is calculated by the method described by Matthews (1961), and depends on the principle that the specific activity of the plasma alters only through the influx of unlabelled albumin into the circulation. If equilibrium were present, this would be almost, if not all, composed of freshly synthesized albumin, and the rate of its production could be calculated from changes in specific activity. However, complete equilibrium probably does not exist, and therefore the 'synthesis rate' as so assessed may not accurately represent true synthesis.

Electrophoresis of the gastric juice concentrated 10 times showed a prominent albumin band (Fig. 2).

SUBSEQUENT COURSE The patient became progressively more anaemic, and his haemoglobin had fallen to $6.6 \mathrm{~g} . / 100 \mathrm{ml}$. ( $44 \%$ ) by $9 \mathrm{March}$. He was therefore given 3 pints of blood by intravenous infusion, so increasing the haemoglobin to $9 \cdot 8 \mathrm{~g} . / 100 \mathrm{ml}$. (65\%), but not reducing the oedema. It was felt that the low plasma albumin level was due to a protein-losing gastropathy associated with pyloric stenosis secondary either to a duodenal ulcer or perhaps to carcinoma of the pylorus, and he was therefore prepared for surgery. He was given a lowsodium diet ( $22 \mathrm{mEq}$./day) and after a control period Dytac (SKF 8542), $150 \mathrm{mg}$. daily, was given, with a dramatic loss of oedema and fall in weight (Fig. 3).

Laparotomy was carried out on 24 April by Mr. F. Forty. He found an infiltrating carcinoma completely surrounding and obstructing the pylorus, but not ulcerating into the gastric lumen. Enlarged mesenteric glands were present. Above the carcinoma, the gastric mucosa was atrophic and in places erosion was present. There was a considerable quantity of free fluid in the peritoneal cavity. Resection of the carcinoma was possible and a Polya gastrectomy was carried out.

Following the operation the patient's condition deteriorated further. Bowel movements did not begin again until four days after the operation, and even then he continued to vomit after taking any food, either solid or fluid. He developed a chest infection and died on 2 May.

Histology of the stomach showed a poorly differentiated adenocarcinoma which became progressively more undifferentiated as it spread through the wall to the serous surface. Only a few scattered groups of tumour cells showed evidence of mucous secretion. Around the edge of the tumour there was intense infiltration with eosinophils. 
Sections from the fundus of the stomach above the carcinoma showed subacute gastritis with some atrophy of the mucosa. There was a cellular infiltrate consisting of plasma cells, polymorphs, eosinophils, and lymphocytes. The lymphoid follicles were more prominent than normal.

NECROPSY FINDINGS (Dr. D. Williams) The body was that of an emaciated man. There was a small volume of clear fluid in each pleural cavity, and both lower lobes showed severe bronchopneumonic changes. The oesophagus was normal, and the stomach contained an intact anastomosis following partial gastrectomy. All the carcinoma had been removed, but there was one gland in the porta hepatis macroscopically affected by secondary carcinoma. On microscopy this proved to be necrotic anaplastic carcinoma. Sections of the oesophagus and jejunum showed no abnormality.

\section{DISCUSSION}

The mechanism of protein loss into the bowel in gastrointestinal disease is obscure. In this case, isotope studies showed that protein was being lost in the stomach and electrophoresis of gastric juice showed a prominent albumin band. Schwartz and Jarnum (1959) studied the faecal excretion of ${ }^{131}$ I - P.V.P. in three patients with gastric carcinoma and showed a very large loss in one of them who had a widespread inoperable lesion. They did not believe that this was due to haemorrhage but that the disorder was analagous to that in hypertrophic gastritis, and studies in a further group of patients with gastric carcinoma gave similar results (Jarnum and Schwartz, 1960). Heiskell et al. (1961) studied the gastric juice of nine patients with gastric carcinoma and demonstrated normal serum protein components in them all. Few of their specimens showed evidence of haemoglobin in amounts detectable by O-toluidine tests and they concluded that the protein loss was due to phenomena more complex than simple bleeding. In the present case, although there was evidence of chronic blood loss in the stools, and the patient had an irondeficiency type of anaemia, it was not felt that this alone could account for the profound decrease in the plasma albumin level. Such a degree of anaemia is not uncommon in gastric carcinoma, but marked hypoalbuminaemia is rarely seen. Nor was this due simply to an inadequate ability to synthesize albumin together with chronic blood loss, for the 'synthesis rate' was shown to be well above the normal range but still insufficient to replace the albumin lost.

Another possible mechanism for loss of protein might be excessive mucous secretion from an adenocarcinoma, but in this case a few groups of cells only showed evidence of mucous secretion.

It has been shown that ulcerative lesions of the gastrointestinal tract may be associated with increased loss of protein through the bowel (Steinfeld, Davidson, and Gordon, 1957; Dawson, Williams, and Williams, 1961), but in the present case ulceration was not present, although as the normal mucosa had been replaced by carcinomatous mucosa it is possible that the same mechanism was operative. Dich, Paaby, and Schwartz (1961) described hypoproteinaemia due to a proteinsecreting polypoid tumour of the stomach which was cured by removal of the polyp. Unfortunately in the present case it was not possible to repeat isotope studies following resection of the carcinoma.

The mucosa in the remainder of the stomach in this case was atrophic, and it is possible that protein was lost mainly from this portion. Several workers have demonstrated loss of protein in steatorrhoea associated with atrophy of the mucosa of the small intestine (Schwartz and Jarnum, 1959; Parkins, 1960; Dawson et al., 1961; Jeejeebhoy, 1962). Heiskell et al. (1961) suggest that serum protein components are more likely to be found in association with achlorhydria and decreased peptic secretion than with normal gastric enzymatic activity.

Another feature of interest was the rapid disappearance of the oedema following treatment with a low-salt diet and a diuretic, SKF 8542, recently introduced for clinical trial (Donnelly, Turner, and Sowry, 1962).

We wish to thank Drs. N. F. Coghill and K. N. Jeejeebhoy of the West Middlesex Hospital for their assistance and for carrying out isotope studies, Drs. J. Hamilton Paterson and D. Williams for the pathological reports, Mr. F. Forty for permission to publish the operative findings, and Smith, Kline, and French Laboratories Limited for the supply of Dytac (SKF 8542).

\section{REFERENCES '}

Dawson, A. M., Williams, R., and Williams, H. S. (1961). Faecal P.V.P. excretion in hypoalbuminaemia and gastrointestinal disease. Brit. med. J., 2, 667-670.

Dich, J., Paaby, H., and Schwartz, M. (1961). Protein-secreting tumour of stomach: severe hypoproteinaemia cured by removal of gastric polyp. Ibid., 2, 686-688.

Donnelly, R. J., Turner, P., and Sowry, G. S. C. (1962). Clinical trial of new oral diuretic-SKF 8542. Lancet, 1, 245-247.

Heiskell, C. L., Wada, T., Stempien, S. J., Fukuda, M., Nakagawa, S., Yachi, A., Dagradi, A., and Carpenter, C. M. (1961). Normal serum proteins in gastric juice. Gastroenterology, 40, 775-781.

Jarnum, S., and Schwartz, M. (1960). Hypoalbuminemia in gastric carcinoma. Ibid., 38, 769-776.

Jeejeebhoy, K. N., and Coghill, N. F. (1961). The measurement of gastrointestinal protein loss by a new method. Gut, 2, 123-130. (1962). Cause of hypoalbuminaemia in patients with gastrointestinal and cardiac disease. Lancet, 1, 343-348.

Matthews, C. M. (1961). Effects of plasmapheresis on albumin pools in rabbits. J. clin. Invest., 40, 603-610.

Parkins, R. A. (1960). Protein-losing enteropathy in the sprue syndrome. Lancet, 2, 1366-1369.

Schwartz, M., and Jarnum, S. (1959). Gastrointestinal protein loss in idiopathic (hypercatabolic, hypoproteinaemia. Ibid., 1, 327-330.

Steinfeld, J. L., Davidson, J. D., and Gordon, R. S. Jr. (1957). A mechanism for hypoalbuminemia in patients with ulcerative colitis and regional enteritis. $J$. clib. Invest., 36, 931. 